\title{
THE EFFECT OF EARLY AND LATE FEEDING AND GLUCAGON UPON BLOOD SUGAR AND SERUM BILIRUBIN LEVELS OF PREMATURE BABIES
}

BY

\author{
J. C. HAWORTH and J. D. FORD \\ From the Department of Paediatrics, University of Manitoba, the Newborn Service, Winnipeg General Hospital \\ and the Winnipeg Clinic, Winnipeg, Canada
}

(RECEIVED FOR PUBLICATION JANUARY 11, 1963)

Many problems relating to the premature baby have received intensive study during the past few decades. This has resulted in more efficient care of the premature with a subsequent decrease in the mortality rate. It is surprising, however, that there is still so much difference of opinion regarding the feeding of premature babies, not only with respect to the type of food but also to the timing of the first feed.

Former authorities apparently favoured early feeding. For instance Goodhart (1913) wrote: 'these feeble infants must not be allowed to wait two or three days for regular feeding with the mother's milk; the loss of weight and possible rise of temperature which such waiting involves-may be the last straw for one of these infants, who is fighting a feeble struggle for existence'. Hess (1923) recommended that milk should be given to premature babies from 12 hours of age; he stated, 'the necessity of an early supply of food cannot be over-emphasized, as even the better developed infants do not withstand prolonged starvation'.

During the past decade or so a number of writers have advised that feeds should be withheld from premature babies for periods of 12 to 96 hours depending upon the degree of immaturity at birth, mainly on the grounds that the premature is particularly liable to pneumonia due to the aspiration of vomit. Newborn premature infants frequently manifest oedema suggesting that they are overhydrated, and Smith (Smith, Yudkin, Young, Minkowski and Cushman, 1949; Hansen and Smith, 1953; Smith, 1957) has shown that relatively large amounts of water and solutes are excreted during the first few days of life, the rate of excretion being proportional to the degree of oedema. He recommended that feeding should be delayed for as long as four days. Although thirsting babies were unable to maintain homeostasis, clinically their condition remained satisfactory and any haemoconcentration was promptly reversed after one day's fluid intake. Recently Smith (1962) appears to have had second thoughts about the advisability of an initial starvation period. Gaisford and Schofield (1950) were also strong protagonists of a three-tofour-day starvation period for premature infants. They thought the time of the first feeding should be determined by the strength of the cry and the disappearance of oedema. Crosse (1957) wrote about the possible dangers of overfeeding during the first week of life and considered that the survival rate of premature infants had been improved by giving nothing by mouth for several days after birth. She recommended starvation periods varying from 12 hours to four days depending upon the birth weight.

Ylppö (1954) challenged the concept that prematures should be starved initially, believing that fasting caused acidosis and disturbances of renal function. He compared the effects of early and late feeding régimes in two hospitals and found little difference in mortality rates. He considered that prematures should be given fluid and food as early as possible.

There appear to have been very few controlled studies on premature infant feeding. Gleiss (1955) reported a mortality of $41 \%$ in 92 babies first fed at 36 hours of age, and a mortality of $28 \%$ in 102 infants first fed between 12 and 24 hours. These death rates are very high and it is not clear what kind of baby he was studying. Analysis of his figures of mortality show that they are not statistically significant $\left(\chi^{2}=2 \cdot 99\right)$. Bauman (1960) studied 50 premature babies; 26 were given no fluids for 24 hours, 24 received glucose and saline by 
intragastric drip 'as soon after admission as possible'. He found no difference in mortality or morbidity in the two groups of babies and concluded that early feeding resulted in neither beneficial nor detrimental effects. Laurance and Smith (1962) compared a group of 29 babies who were first fed before 9 hours of age with another group (39 babies) who were fed at 12 to 56 hours. There were more cases of jaundice and respiratory distress and more deaths in the latter group of infants.

The infant born to a diabetic mother, despite its size, is in many respects similar to the premature infant, particularly in its susceptibility to respiratory complications, hyperbilirubinaemia and hypoglycaemia. Delay in the feeding of these babies has also been advocated (Gellis and Hsia, 1959). However, Reardon, Field, Vega, Carrington, Arey and Baumann (1957) reported a lower mortality rate from 'hyaline membrane disease' in babies who received $30 \mathrm{ml} . / \mathrm{lb} . /$ day of $5 \%$ glucose and $0.45 \%$ saline from 2 to 12 hours of age. Hubbell, Drorbaugh, Rudolph, Auld, Cherry and Smith (1961) in a controlled study of early and late feeding in 48 pairs of infants of diabetic mothers reported no advantage of routine early feeding as treatment for hyaline membrane disease but found that the group fed early had significantly lower serum indirect bilirubin levels at 72 hours of age, which was not due to a haemodilution. Since severe jaundice is a complication common to infants of diabetic mothers as well as of premature infants, the observations of Hubbell et al. (1961) and of Laurance and Smith (1962) suggested that early feeding of these two groups of babies might reduce the incidence of hyperbilirubinaemia and lessen the need for exchange transfusion.

A mechanism by which the administration of glucose might lower the serum indirect bilirubin level has been suggested by Brown (1962). Glucose is the substrate from which uridine diphosphate glucuronic acid is formed with which bilirubin is conjugated to form bilirubin glucuronide. Although deficiency of the enzyme glucuronyl transferase is the main causative factor in neonatal 'physiological' jaundice, it is also possible that the hypoglycaemia of the newborn may be contributory due to lack of available glucose.

This paper describes a controlled trial designed to compare the effects of early and delayed feeding upon the blood sugar and indirect serum bilirubin levels of two groups of premature infants. In a third group feedings were delayed but glucagon was administered in an attempt to assess whether the mobilization of the infants' own carbohydrate stores would affect these factors.

\section{Clinical Material and Methods}

This study was made on newborn babies weighing $5 \mathrm{lb} .8 \mathrm{oz} .(2 \cdot 5 \mathrm{~kg}$.) or less during a six-month period at the Women's Pavilion of the Winnipeg General Hospital. The cases were consecutive except that for about a month the trial was discontinued because a laboratory technician left and another had to be trained in the microbiochemical techniques. Also it was found to be too heavy a load for the nursing and laboratory staff if more than three babies were on the trial at the same time, and therefore on one or two occasions infants who would have been eligible were excluded from the trial if three babies were already in process of study.

Each infant was allocated to one of three treatment groups by opening one of a shuffled pile of envelopes containing cards labelled Group 1,2 or 3 . This was done on the arrival of the baby in the premature nursery after transfer from the labour floor and within four hours of birth. Infants who showed signs of respiratory distress, sepsis or haemolytic disease of the newborn at this time were excluded.

The groups were as follows:

Group 1: 'Early fed group'. These babies received feedings of $5 \%$ glucose in water starting at 4 to 6 hours of age in a daily volume of $30 \mathrm{ml}$./lb. The infants were fed every three hours (at 1, 4, 7 and 10 a.m. and p.m.) either by bottle or through an indwelling polyethylene tube.

Group 2: 'Glucagon group'. These babies received no feeding for 36 hours but glucagon $(0.1 \mathrm{mg} . / \mathrm{kg}$.) was administered by intramuscular injection three hourly (at 1, 4, 7 and 10 a.m. and p.m.) for 36 hours.

Group 3: 'Delayed feeding group'. No feeding was given for 36 hours.

After 36 hours of age all the infants received the routine nursery feedings three hourly, the times of the feeding being the same as above. The infants were nursed in incubators, oxygen being administered if necessary. Each baby received vitamin K $1 \mathrm{mg}$. intramuscularly on the first day of life. Antibiotics were used at the discretion of the physician but no baby received sulphonamides.

The following observations were made for the first five days of life: at 9.30 a.m. weight, haematocrit, serum bilirubin and blood sugar; at 12.30 and 3.30 p.m. blood sugar.

The haematocrit was included in order that the factor of haemodilution could be assessed should the serum bilirubin levels in Group 1 differ from the other groups.

A preliminary analysis of the blood sugar levels was made after the first 36 babies ( 12 in each group) had been studied. Since no significant difference between the groups was apparent, blood sugar estimations were not made upon the remainder of the babies.

Serum bilirubin was measured by the method of Malloy and Evelyn (1937) within two hours of collection. Serum samples were protected from light until the estimation was performed.

Blood sugar estimations were performed on capillary blood by the method of King and Garner (1947). The 
TABLE 1

DETAILS OF THE 45 PREMATURE INFANTS STUDIED

\begin{tabular}{|c|c|c|c|c|c|c|c|c|}
\hline Group & No. & Sex & $\begin{array}{c}\text { Mean } \\
\text { Birth Weight } \\
\text { (g.) }\end{array}$ & $\begin{array}{c}\text { Mean } \\
\text { Gestation } \\
\text { (weeks) }\end{array}$ & $\begin{array}{c}\text { Mean Age } \\
\text { When First } \\
\text { Blood Sample } \\
\text { Taken (hrs.) }\end{array}$ & $\begin{array}{l}\text { Mode of } \\
\text { Delivery }\end{array}$ & $\begin{array}{c}\text { Maternal } \\
\text { Complications }\end{array}$ & $\begin{array}{c}\text { No. of } \\
\text { Babies } \\
\text { Receiving } \\
\text { Antibiotics }\end{array}$ \\
\hline 1 & $15^{*}$ & $\begin{array}{l}\text { Male (4) } \\
\text { Female (11) }\end{array}$ & 1,869 & $35 \cdot 0$ & $11 \cdot 1$ & $\begin{array}{l}\text { Vertex (11) } \\
\text { Breech (4) }\end{array}$ & $\begin{array}{l}\text { Toxaemia (2) } \\
\text { Antepartum } \\
\text { haemorrhage } \\
\text { (1) }\end{array}$ & 2 \\
\hline 2 & 15 & $\begin{array}{l}\text { Male (7) } \\
\text { Female (8) }\end{array}$ & 1,869 & 35.9 & $12 \cdot 5$ & $\begin{array}{l}\text { Vertex (10) } \\
\text { Face (1) } \\
\text { Caesarian (1) } \\
\text { Breech (3) }\end{array}$ & $\begin{array}{l}\text { Toxaemia (1) } \\
\text { Antepartum } \\
\text { haemorrhage } \\
\text { (1) }\end{array}$ & 2 \\
\hline 3 & $15 \dagger$ & $\begin{array}{l}\text { Male (13) } \\
\text { Female (2) }\end{array}$ & 2,038 & $35 \cdot 1$ & $8 \cdot 7$ & $\begin{array}{l}\text { Vertex (12) } \\
\text { Breech (3) }\end{array}$ & $\begin{array}{l}\text { Toxaemia (1) } \\
\text { Antepartum } \\
\text { haemorrhage } \\
\text { (2) }\end{array}$ & 3 \\
\hline
\end{tabular}

* One female infant in Group 1 (birth weight $4 \mathrm{lb} .10 \mathrm{oz}$. (2,095 g.)) born by breech delivery was unable to tolerate feedings, which were stopped, and the case was discarded for further analysis.

$\dagger$ One male infant in Group 3 (birth weight 2 lb. 9 oz. (965 g.)) born by vertex delivery, died at 48 hours of age. Data included until time of death.

blood was immediately mixed with a copper sulphate, sodium sulphate solution which prevents glycolysis.

\section{Results}

Forty-five infants were included in the trial, 15 in each group. One infant in Group 3 died at 48 hours of age with cerebral haemorrhage and atelectasis. Data obtained from this baby until death are included in the analysis of the results. One baby in Group 1 became cyanosed during feeding; the feedings were therefore stopped and the case discarded from the series. All the other babies in Group 1 tolerated the glucose well; none developed aspiration pneumonia. The subsequent progress of the 44 surviving infants was satisfactory until they were discharged from hospital.

Comparison of the infants in each group is made in Table 1. Their birth weights, estimated length of gestation, mode of delivery and the age when the first blood sample was obtained were not significantly different in the three groups. Approximately the same number of babies in each group received antibiotics and there was no difference in

TABLE 2

MEAN PERCENTAGE HAEMATOCRIT VALUES \pm STANDARD DEVIATION

\begin{tabular}{|c|c|c|c|c|c|}
\hline \multirow{2}{*}{ Group } & \multicolumn{5}{|c|}{ Days } \\
\hline & 1 & 2 & 3 & 4 & 5 \\
\hline 1 & $\begin{array}{r}68 \cdot 7 \\
\pm 6.8\end{array}$ & $\begin{array}{r}66 \cdot 6 \\
\pm 6.2\end{array}$ & $\begin{array}{r}68 \cdot 2 \\
\pm 5.4\end{array}$ & $\begin{array}{r}63 \cdot 1 \\
\pm 6 \cdot 3\end{array}$ & $\begin{array}{r}62 \cdot 1 \\
\pm 6 \cdot 1\end{array}$ \\
\hline 2 & $\begin{array}{r}67.0 \\
\pm 9 \cdot 6\end{array}$ & $\begin{array}{r}58.7 \\
\pm 8.9\end{array}$ & $\begin{array}{r}64 \cdot 4 \\
\pm 9 \cdot 1\end{array}$ & $\begin{array}{r}58 \cdot 7 \\
\pm 8 \cdot 7\end{array}$ & $\begin{array}{r}55.6 \\
\pm 6.2\end{array}$ \\
\hline 3 & $\begin{array}{r}70 \cdot 6 \\
\pm 11.5\end{array}$ & $\begin{array}{r}63 \cdot 6 \\
\pm 11 \cdot 7\end{array}$ & $\begin{array}{r}64 \cdot 3 \\
\pm 9 \cdot 7\end{array}$ & $\begin{array}{r}60.9 \\
\pm 10.1\end{array}$ & $\begin{array}{r}61 \cdot 4 \\
\pm 6.5\end{array}$ \\
\hline
\end{tabular}

the incidence of maternal complications. Unfortunately it happened by chance that there were more females in Group 1 and more males in Group 3.

Haematocrit Values. The mean haematocrit values are expressed in Table 2. Variation between the values obtained on each day was large and there was no statistically significant difference between the three groups. The degree of fall with age was also not significantly different in the groups.

Blood Sugar Levels. The mean blood sugar levels of 36 infants are shown in Table 3 and Fig. 1. The variation was considerable and comparison of the mean levels on any one day and at the three different times during the day showed no statistically significant differences between the three groups. As expected, there was a tendency for the fasting blood sugar to increase with age. Blood sugar values below $20 \mathrm{mg}$./100 ml. were found in 37 blood samples from 20 babies (six in Group 1 and seven each in Groups 2 and 3) and below $10 \mathrm{mg} . / 100 \mathrm{ml}$. in seven blood samples from six babies (three in Group 1, one in Group 2 and two in Group 3). None of the babies exhibited signs of hypoglycaemia.

Indirect Serum Bilirubin Levels. The mean indirect serum bilirubin levels of 44 infants are shown in Table 4. The levels obtained on any one day did not differ significantly between the groups. The levels exceeded $20 \mathrm{mg}$. $/ 100 \mathrm{ml}$. in three infants in Group 1, one in Group 2 and two in Group 3. In no case was exchange transfusion thought to be necessary.

Weight Loss. The weight loss (expressed as a 


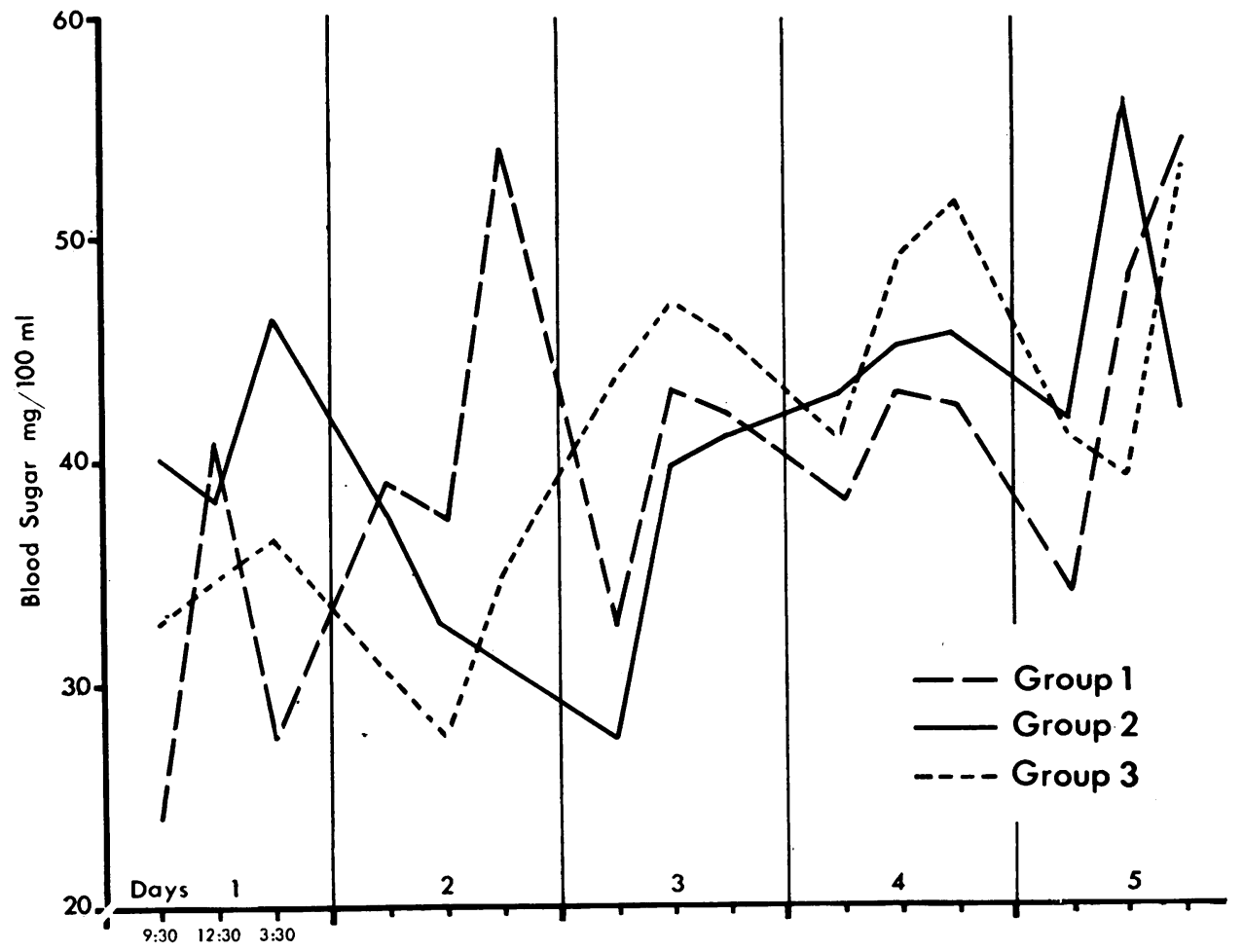

FIGURE.-Graph showing the mean blood sugar levels of the infants in Groups 1, 2 and 3.

percentage of the birth weight) was analysed for Days 2 and 5 as shown in Table 5. The difference in mean percentage weight loss on Day 2 in Groups 2 and 3 (the two delayed feeding groups) as compared with Group 1 is significant at the $5 \%$ level. The differences on Day 5 are not statistically significant.

\section{Discussion}

Under the conditions of this trial early feeding of a group of premature infants with glucose had no demonstrable effect upon their indirect serum bilirubin levels and fasting blood sugar concentrations as compared with the group in whom feedings were delayed for 36 hours. We were thus unable to confirm the findings of Hubbell et al. (1961) and of Laurance and Smith (1962). The former were, however, studying babies of diabetic mothers and not prematures and the feedings in this report were delayed longer than in our series.

TABLE 3

MEAN BLOOD SUGAR LEVELS ( \pm STANDARD DEVIATION) in mg./100 ml.

\begin{tabular}{|c|c|c|c|c|c|c|}
\hline \multirow{2}{*}{ Group } & \multirow{2}{*}{ Time } & \multicolumn{5}{|c|}{ Days } \\
\hline & & 1 & 2 & 3 & 4 & 5 \\
\hline 1 & $\begin{array}{r}9.30 \\
12.30 \\
3.30\end{array}$ & $\begin{array}{l}24 \cdot 4 \pm 10 \cdot 1 \\
40 \cdot 9 \pm 21 \cdot 9 \\
27 \cdot 5 \pm 22.6\end{array}$ & $\begin{array}{r}39 \cdot 0 \pm 13 \cdot 7 \\
37.5 \pm 8.6 \\
54.0 \pm 18 \cdot 8\end{array}$ & $\begin{array}{l}32 \cdot 5 \pm 15 \cdot 8 \\
42.9 \pm 16 \cdot 3 \\
42 \cdot 1 \pm 11 \cdot 5\end{array}$ & $\begin{array}{r}38.2 \pm 11.4 \\
43.8 \pm 10.5 \\
42.4 \pm 9.1\end{array}$ & $\begin{array}{l}33.8 \pm 15.5 \\
47.9 \pm 15.1 \\
54.6 \pm 20.0\end{array}$ \\
\hline 2 & $\begin{array}{r}9.30 \\
12.30 \\
3.30\end{array}$ & $\begin{array}{l}40 \cdot 1 \pm 19 \cdot 3 \\
38 \cdot 1 \pm 11 \cdot 9 \\
46.4 \pm 11 \cdot 9\end{array}$ & $\begin{array}{r}37 \cdot 7 \pm 11 \cdot 0 \\
32 \cdot 5 \pm 7 \cdot 8 \\
31 \cdot 1 \pm 17 \cdot 8\end{array}$ & $\begin{array}{l}27.7 \pm 17.7 \\
39.7 \pm 22.7 \\
41.0 \pm 17.4\end{array}$ & $\begin{array}{l}43 \cdot 3 \pm 18 \cdot 1 \\
45 \cdot 3 \pm 15 \cdot 9 \\
45 \cdot 7 \pm 19 \cdot 8\end{array}$ & $\begin{array}{l}41 \cdot 7 \pm 17 \cdot 7 \\
56 \cdot 7 \pm 13 \cdot 5 \\
42 \cdot 7 \pm 18 \cdot 8\end{array}$ \\
\hline 3 & $\begin{array}{r}9.30 \\
12.30 \\
3.30\end{array}$ & $\begin{array}{l}32.7 \pm 11.9 \\
34.6 \pm 17.7 \\
36.4 \pm 15.4\end{array}$ & $\begin{array}{l}30 \cdot 6 \pm 10 \cdot 6 \\
27 \cdot 5 \pm 12.0 \\
34 \cdot 8 \pm 14.0\end{array}$ & $\begin{array}{l}43.7 \pm 28 \cdot 8 \\
46.9 \pm 20.7 \\
45.6 \pm 14.6\end{array}$ & $\begin{array}{l}41 \cdot 1 \pm 12 \cdot 3 \\
48 \cdot 9 \pm 11 \cdot 3 \\
51 \cdot 5 \pm 15 \cdot 0\end{array}$ & $\begin{array}{l}41 \cdot 2 \pm 16 \cdot 0 \\
39 \cdot 3 \pm 23 \cdot 4 \\
53 \cdot 1 \pm 19 \cdot 1\end{array}$ \\
\hline
\end{tabular}


TABLE 4

MEAN INDIRECT SERUM BILIRUBIN LEVELS $( \pm$ STANDARD DEVIATION) IN $\mathrm{mg} . / 100 \mathrm{ml}$.

\begin{tabular}{|c|c|c|c|c|c|}
\hline \multirow{2}{*}{ Group } & \multicolumn{5}{|c|}{ Days } \\
\hline & 1 & 2 & 3 & 4 & 5 \\
\hline 1 & $\begin{array}{r}5.5 \\
\pm 1.0\end{array}$ & $\begin{array}{r}7 \cdot 9 \\
\pm 3 \cdot 2\end{array}$ & $\begin{array}{r}11 \cdot 6 \\
\pm 3 \cdot 7\end{array}$ & $\begin{array}{r}15 \cdot 3 \\
\pm 5 \cdot 2\end{array}$ & $\begin{array}{r}15 \cdot 6 \\
\pm 7 \cdot 0\end{array}$ \\
\hline 2 & $\begin{array}{r}4 \cdot 4 \\
\pm 2 \cdot 2\end{array}$ & $\begin{array}{r}7.9 \\
\pm 2.8\end{array}$ & $\begin{array}{r}10 \cdot 8 \\
\pm 3.5\end{array}$ & $\begin{array}{r}13 \cdot 7 \\
\pm 2 \cdot 2\end{array}$ & $\begin{array}{r}15 \cdot 3 \\
\pm 1 \cdot 0\end{array}$ \\
\hline 3 & $\begin{array}{r}4 \cdot 1 \\
\pm 1 \cdot 2\end{array}$ & $\begin{array}{r}9.6 \\
\pm 1.8\end{array}$ & $\begin{array}{r}12 \cdot 6 \\
\pm 3 \cdot 3\end{array}$ & $\begin{array}{r}13 \cdot 3 \\
\pm 5 \cdot 2\end{array}$ & $\begin{array}{r}13 \cdot 5 \\
\pm 3 \cdot 7\end{array}$ \\
\hline
\end{tabular}

In the report of Laurance and Smith jaundice was estimated by means of an icterometer and serum bilirubin estimations were not apparently made.

It is of some interest that neither three-hourly glucose feedings nor the three-hourly injection of glucagon protected the infants from fasting hypoglycaemia. It is true that the amount of glucose fed to the babies in Group 1 was small (about $0 \cdot 2 \mathrm{~g}$./lb./feeding), but we were limited by the volume of fluid that we felt the infants could tolerate. In one infant we performed half-hourly blood sugar estimations after the feeding and found a rise of $35 \mathrm{mg}$./100 ml. at one hour with a subsequent fall to the fasting level at two and a half hours. We have previously observed the difficulty in controlling the hypoglycaemia of newborn infants by means of glucose feeding (Haworth, Coodin, Finkel and Weidman, 1963). The hyperglycaemic effect of glucagon in the newborn is also limited to two to three hours (Cornblath, Ganzon, Nicolopoulos, Baens, Hollander, Gordon and Gordon, 1961; Mulligan and Schwartz, 1962).

In 20 infants fasting blood sugar levels below $20 \mathrm{mg}$. $/ 100 \mathrm{ml}$. were recorded on one or more occasions and six had levels below $10 \mathrm{mg} . / 100 \mathrm{ml}$. None of these babies exhibited symptoms of hypoglycaemia. A note was made of the behaviour of each infant at the time of the blood examination and on many occasions when the blood sugar was very low the baby was sleeping quietly until pricked, when he responded normally by crying. Such profound hypoglycaemia without symptoms in premature infants has been noticed previously by us

TABLE 5

MEAN PERCENTAGE WEIGHT LOSS

\begin{tabular}{c|c|c}
\hline Group & Day 2 & Day 5 \\
\hline 1 & $3 \cdot 2$ & $3 \cdot 6$ \\
2 & $5 \cdot 4$ & $6 \cdot 1$ \\
3 & 6.0 & $3 \cdot 8$ \\
\hline
\end{tabular}

(Haworth and Ford, 1960) as well as by others (Norval, 1950). Baens, Oh, Lundeen and Cornblath (1961) have rightly emphasized that erroneously low blood sugar values may be obtained unless careful precautions are taken to avoid glycolysis after the blood has been drawn. All the blood samples taken for sugar analysis from the babies in this report were treated immediately with sodium sulphate and copper sulphate after the method of King and Garner (1947) and glycolysis could not have been significant.

Hypoglycaemia in the newborn infant is undoubtedly sometimes associated with severe symptoms (Cornblath, Odell and Levin, 1959; Haworth et al., 1963), but what factor determines whether or not symptoms occur with low blood sugar levels remains unanswered. We do not feel confident in stating that severe hypoglycaemia is harmless even in the absence of overt symptoms in the neonatal period; it is possible that in some cases mental retardation of varying degree may be attributed to it. It has not yet been possible to obtain follow-up details of the infants studied in the present series from this aspect, but we are planning to do so at a later date.

Infants showing signs of the 'respiratory distress syndrome' were excluded from this trial because at the Winnipeg General Hospital this condition is treated with intravenous fluids along the lines suggested by Usher (1959). No baby developed symptoms of respiratory distress after inclusion in the trial as would be expected since the 'respiratory distress syndrome' manifests itself at birth or within the first hour or two of life (Driscoll and Smith, 1962). For this reason 'early' feeding starting at 4 to 6 hours of age could have no possible effect in preventing the condition as suggested by Laurance and Smith (1962). Only one of the infants in the early-fed group (Group 1) showed any ill effects from the feeding, indicating that aspiration of vomit is not a hazard with the use of an indwelling polyethylene catheter in the smaller babies provided the nursing staff is experienced in this technique. The babies in whom feedings were delayed (Groups 2 and 3) had lost more weight on the second day of life compared with those in Group 1, but the loss was not great. By the fifth day there was no significant difference in the weights of the babies in the three groups.

We have therefore been unable to demonstrate either advantage or disadvantage in feeding premature infants from 4 to 6 hours of age from the standpoints of mortality, morbidity or the effect on the fasting blood sugar or indirect serum bilirubin level. Whether the time of the first feeding 
may influence premature babies in other respects will only be determined by further studies.

\section{Summary}

A controlled clinical trial was conducted to assess the effect of early and late feeding and of glucagon upon the fasting blood sugar and indirect serum bilirubin levels of normal premature babies during the first five days of life.

No statistically significant differences in blood sugar and serum bilirubin levels were found in 44 babies whether they were fed with glucose from 4 to 6 hours of age or fasted for 36 hours or fasted for 36 hours and given glucagon. Early glucose feedings and glucagon given every three hours does not protect the premature infant from fasting hypoglycaemia. The babies who were fasted for 36 hours lost more weight on the second day of life than those who were fed early.

One of 15 babies was unable to tolerate glucose feeds given from 4 to 6 hours of age. The other 14 showed no ill effects from early feeding.

There appeared to be neither advantages nor disadvantages in feeding premature infants from 4 to 6 hours of age or delaying feedings for 36 hours.

We wish to thank Professor Harry Medovy for his advice before and during this trial, and him and Dr. K. C. Finkel for reviewing the manuscript. Dr. R. J. Cadoret gave us assistance in analysing the results, and Miss Beth Gourley advised on a number of biochemical problems. We also thank Miss P. Cooke and Mrs. L. Dilling for technical assistance and a number of physicians for permission to study patients under their care. Finally, this trial would not have been possible without the co-operation of Miss J. M. Cookson, S.R.N., and her nursing staff in the premature nursery of the Winnipeg General Hospital.

\section{REFERENCES}

Baens, G. S., Oh, W., Lundeen, E. and Cornblath, M. (1961). Determination of blood sugar in newborn infants. Pediatrics, 28, 850 .
Bauman, W. A. (1960). Early feeding of dextrose and saline solution to premature infants. ibid., 26, 756.

Brown, A. K. (1962). Bilirubin metabolism with special reference to neonatal jaundice. Advanc. Pediat., 12, 121 .

Cornblath, M., Ganzon, A. F., Nicolopoulos, D., Baens, G. S., Hollander, R. J., Gordon, M. H. and Gordon, H. H. (1961). Studies of carbohydrate metabolism in the newborn infant, III. Some factors influencing the capillary blood sugar and the response to glucagon during the first hours of life. Pediatrics, response 378 .

Ódell, G. B. and Levin, E. Y. (1959). Symptomatic neonatal hypoglycemia associated with toxemia of pregnancy. J. Pediat. 55,545 .

Crosse, V. M. (1957). The Premature Baby, 4th ed. Churchill, London.

Driscoll, S. G. and Smith, C. A. (1962). Neonatal pulmonary disorders. Pediat. Clin. N. Amer., 9, 325.

Gaisford, W. and Schofield, S. (1950). Prolongation of the initial starvation period in premature infants. Brit med. $J, 1,1404$.

Gellis, S. S. and Hsia, D. Y-Y. (1959). The infant of the diabetic mother. A.M.A. Amer. J. Dis. Child., 97, 1.

Gleiss, J. (1955). Zum Frühgeborenenproblem der Gegenwart. IX Mitteilung. $Z$. Kinderheilk., 76, 261.

Goodhart, J. F. (1913). The Diseases of Children, edited and revised by G. F. Still, 10th ed., p. $36 . \quad$ Churchill, London.

Hansen, J. D. L. and Smith, C. A. (1953). Effects of withholding fluid in the immediate postnatal period. Pediatrics, 12, 99.

Haworth J. C. Coodin, F. J. Finkel, K C and Weidman, (1963). Hypoglycemia associated with symptoms in the newborn period. Canad. med. Ass. J., 88, 23.

and Ford, J. D. (1960). Blood-sugar in infants after lactose feeds. Lancet, 2, 794.

Hess, J. H. (1923). Infant Feeding, A Handbook for the Practitioner, p. 55. American Medical Association, Chicago.

Hubbell, J. P., Drorbaugh, J. E., Rudolph, A. J., Auld, P. A. M., Cherry, R. B. and Smith, C. A. (1961). 'Ëarly' versus 'late' feeding of infants of diabetic mothers. New Engl. J. Med., 265,835 .

King, E. J. and Garner, R. J. (1947). The colorimetric determination of glucose. J. clin. Path., 1, 30.

Laurance, B. M. and Smith, B. H. (1962). The premature baby's diet. Lancet, 1, 589.

Malloy, H. T. and Evelyn, K. A. (1937). Determination of bilirubin with photoelectric colorimeter. J. biol. Chem., 119, 481.

Mulligan, P. B. and Schwartz, R. (1962). Hepatic carbohydrate metabolism in the genesis of neonatal hypoglycemia. Effects of the administration of epinephrine, glucagon and galactose. of the administratios, 30, 125 .

Norval, M. A. (1950). Blood sugar values in premature infants. J. Pediat., 36, 177.

Reardon, H. S., Field, S., Vega, L., Carrington, E., Arey, J. and Baumann, M. L. (1957). Treatment of acute respiratory distress in newborn infants of diabetic and 'prediabetic' mothers. A.M.A. Amer. J. Dis. Child., 94, 558.

Smith, C. A. (1957). Reasons for delaying the feeding of premature infants. Ann. Paediat. Fenn., 3, 261.

infants. Ann. Paediat. Fenn., 3, 261. Yudkin, S., Young, W., Minkowski, A. and Cushman, M. (1949). Adjustment of electrolytes and water following premature birth. ibid., 3, 34.

Usher, R. (1959). The respiratory distress syndrome of prematurity. ibid., 24, 562 .

Ylppö, A. (1954). Premature children-should they fast or be fed in the first days of life? Ann. Paediat. Fenn., 1, 99. 